Sección Control / Control

Artículos de investigación / Research paper

\title{
Heterorhabditis bacteriophora pampean-strain VEli (Nematoda): identification and pathogenicity against the strawberry pest Lobiopa insularis (Coleoptera: Nitidulidae)
}

\author{
Heterorhabditis bacteriophora cepa-VEli (Nematoda): identificación y patogenia sobre Lobiopa insularis \\ (Coleoptera: Nitidulidae) plaga de la fresa \\ DAIANA P. ELICECHE ${ }^{1}$, MARIANO NICOLÁS BELAICH ${ }^{2,3}$, PABLO DANIEL GHIRINGHELLI ${ }^{2,3}$ \\ and MARÍA FERNANDA ACHINELLY ${ }^{1,3}$
}

\begin{abstract}
The pampean region in the Buenos Aires province of Argentina is a major horticultural area. Biological pesticides to control pest insects available in the market are scarce in this country and nonexistent based on entomonematodes. In this paper, we characterized a native entomopathogenic nematode isolated from soil in the pampas, and evaluated its infectivity and reproductive capacity in the strawberry sap beetle Lobiopa insularis. Morphological and molecular-genetic analysis determined this isolate to be a nematode of Heterorhabditis bacteriophora, thereafter designated as the VEli strain. A 901-bp genomic-DNA fragment was isolated (GenBank Accesion No KJ575524). The new strain was pathogenic against L. insularis. In $200 \mathrm{ml}$ containers with autoclaved clay soil (100 ml), at concentrations of 1,$000 ; 5,000$ and $10,000 \mathrm{IJs}$, mortality in larvae ranged from 25 to $77 \%$. At a concentration of 10,000 IJs, infectivity was higher in larvae and pupae $(77 \pm 20 \%$ and $64 \pm 25 \%$, respectively) than in adults $(2.2 \pm 1.1 \%)$. The lethal concentration required to kill 50 and $90 \%$ of the larvae $\left(\mathrm{LC}_{50}\right.$ and $\left.\mathrm{LC}_{90}\right)$ over 10 days was 2,840 and 23,743 IJs. Differences were observed in the parasitism levels and emergence time of IJs between concentrations and stages, although not for production. Heterorhabditis bacteriophora strain VEli is the first entomopathogenic nematode found to infect and kill L. insularis, capable of completing its life cycle in all strawberry sap beetle stages. This availability would enable the establishment and subsequent dispersal of the strain in strawberry fields. Finally, this report constitutes the first presentation of data on the morphological, morphometric, and molecular-genetic characterization of a native entomopathogenic nematode strain from the Buenos Aires province, Argentina.
\end{abstract}

Key words: Entomopathogenic nematodes, Heterorhabditidae, characterization, biological control.

Resumen: En la región pampeana, provincia de Buenos Aires, Argentina, la horticultura es una de las principales actividades agrícolas. Los plaguicidas biológicos disponibles en el mercado son escasos en el país e inexistentes en base a nematodos. En este trabajo, se caracterizó un nematodo entomopatógeno nativo aislado de la pampa y se evaluó su infectividad y capacidad reproductiva en el insecto de las fresas, Lobiopa insularis. El análisis morfológico y genéticomolecular determinó este aislado como el nematodo Heterorhabditis bacteriophora, designado cepa-VEli. Se aisló un fragmento del ADN genómico de 901 pb (acceso GenBank No KJ575524). La nueva cepa fue patógena contra L. insularis. En recipientes de $200 \mathrm{ml}$ con suelo arcilloso autoclavado $(100 \mathrm{ml})$, a concentraciones de 1.000; 5.000 y $10.000 \mathrm{JIs}$, la mortalidad en larvas varió de 25 a $77 \%$. A una concentración de 10,000 JIs, la infección fue mayor en larvas y pupas $(77 \pm 20 \%$ y $64 \pm 25 \%$, respectivamente) que en adultos $(2,2 \pm 1,1 \%)$. La concentración letal requerida para matar 50 y $90 \%$ de las larvas $\left(\mathrm{CL}_{50}\right.$ y $\left.\mathrm{CL}_{90}\right)$ después de 10 días fue 2.840 y 23.743 IJs. Se observaron diferencias en los niveles de parasitismo y en el tiempo de emergencia de los Jis entre concentraciones y estadios aunque no en la producción. Heterorhabditis bacteriophora VEli es el primer nematodo entomopatógeno que infecta y mata L. insularis, capaz de completar su ciclo de vida en todas las etapas del escarabajo de la savia de la fresa. Esta disponibilidad permitiría el establecimiento y posterior dispersión de la cepa en los campos de fresa. Por último, este informe constituye la primera presentación de datos sobre la caracterización morfológica, morfométrica y genética molecular de una cepa nativa de nematodos entomopatógenos para la provincia de Buenos Aires, Argentina.

Palabras clave: Nematodos entomopatógenos, Heterorhabditidae, caracterización, control biológico.

\section{Introduction}

Lobiopa insularis (Castelnau, 1840), a sap beetle (Coleoptera: Nitidulidae), is one of the most economically significant pests of commercial strawberry crops (Fragaria $\times$ ananassa Duchesne) (Fornari et al. 2013; Potter et al. 2013). The range of native habitats comprises almost all areas of North,
Central, and South America (Lasoń and Przewozny 2009). In Argentina is a newly reported pest of strawberry (Greco et al. 2017 ) with damages reaching up to $46 \%$ (affected fruits) in the horticultural area of La Plata, Buenos Aires province (D. Eliceche, pers. com).

These insects are generalist herbivores attacking not only strawberries but also tomato, peach, guava, apple, orange,

\footnotetext{
${ }^{1}$ Centro de Estudios Parasitológicos y de Vectores. CEPAVE (CCT La Plata, CONICET/UNLP), Calle 121 y 60 (1900) La Plata, Buenos Aires, Argentina. ${ }^{2}$ Laboratorio de Ingeniería Genética y Biología Celular y Molecular, UNQ, Buenos Aires, Argentina. ${ }^{3}$ Members of the Research Career of CONICET. Tel.: +54-221-423-3471; Fax: +54-221-423-2327.fachinelly@cepave.edu.ar, corresponding author.
} 
and melon crops, among others; thus undergoing population expansion when a given resource is abundant. They are strongly influenced to volatile plant compounds during fruit ripening or decay. Lin and Phelan (1991) demonstrated that seven volatile compounds (acetaldehyde, ethyl acetate, etanol, 1-propanol 2-methylpropanol 3-methylbutanol, 2-methylbutanol) attracted the sap beetles in the field. In addition to direct damage, L. insularis also serves as fungal dispersal agent, thus increasing yield losses (Dowd et al. 1995; Guimarães et al. 2009).

The larvae and adults feed on ripe fruit causing major damage to fresh-fruit. Females oviposit in the ground, and the larvae pupate within the first $10 \mathrm{~cm}$ (Cluigt et al. 2007). The long life span of adults (up to seven months) and high reproductive output, indicate the presence of several overlapping generations (Bortoli et al. 2014; Greco et al. 2017).

Control of $L$. insularis is based mainly on cultivation practices and chemical-insecticide applications (Botton et al. 2014; Myers 2014). Surpluses of these pesticides are generally dispersed into large areas, causing increased danger to the health of the human population and environment. Furthermore, such pesticide applications can also affect populations of beneficial insects (Nichols Estrada 2008).

Entomopathogenic nematodes (EPNs i. e., comprising the Steinernematidae and Heterorhabditidae) are a group of parasites causing death to insects, utilized in classical, conservation, and augmentative biological-control programs (Lacey et al. 2015). They present a combination of desirable attributes as bioregulators such as their wide host range, the ability to cause high insect mortalities, their environmental friendliness, their facile production at different scales by methods both in vivo and in culture, and the compatibility with various chemicals and other bioregulatory agents (Shapiro-Ilán and Dolinski 2012).

The associations with symbiotic pathogenic bacteria make EPNs highly virulent. The life cycle includes the nonfeeding third-stage infective juveniles (IJs), or "Dauer" larvae, which is the only free-living stage, that gain access into the haemocel of host insects through natural body openings or by penetrating thin cuticles (Lewis et al. 2006). Once inside the host, a symbiotic bacterium is released in the haemolymph that proliferates and produces a wide range of toxins and hydrolytic exoenzymes that are responsible for the death (at 24-48 h post-infection) along with a degradation of the insect's composition into a nutrient soup needed for the nematode's growth and reproduction (Bowen et al. 1998). Nematodes complete one to three generations within the cadaver, and IJs exit to find new a hosts in response to declining nutrients. Nematodes of the genus Heterorhabditis always present a first generation of adult hermaphrodites and, usually, a second and third generation with males and bonafide females (Vega and Kaya 2012).

Environmental conditions can reduce the efficacy of nematode IJs in controlling pests. Native species adapted to local climatic conditions, would be expected to be more likely to survive after release in a given target area (CamposHerrera et al. 2008; Shapiro et al. 1999). Nevertheless, up to the present time, mainly nonnative strains have been used in nematode applications throughout the world since most of commercial species available have been isolated from either North America or Europe (Grewal and Peters 2005).
To date, no biological products -nematodes or otherwiseregistered in Argentina for the control of L. insularis are available, and alternatives to chemical pesticides are needed. Thus, for the regulation of this pest, EPNs may be good biological control candidates.

The objectives of the work reported here was to identify an EPN of native pasture soils in the pampean region of Argentina and to evaluate its infectivity, development, and multiplication in the sap beetle L. insularis under laboratory conditions.

\section{Materials and methods}

Soil sampling and nematode extraction. Soil samples were collected in an organic farm in the location of Villa Elisa (3451'12'S, 58 04'45'W; 9.87 meters above sea level) La Plata, Buenos Aires province, Argentina. This horticultural area is characterized by the intensive cultivation of fresh fruit and vegetable products and family farms where the main cultivated crops are tomato, celery, lettuce, peppers, strawberry, spinach, eggplant, and basil (Ferratto et al. 2010). Soils of this region are argiudol (Imbellone et al. 2010), the average annual temperature is $15.9{ }^{\circ} \mathrm{C}$, and the annual rainfall is about $1,100 \mathrm{~mm}$. Samples were taken with a shovel to a depth of $15 \mathrm{~cm}$ and transported to the laboratory for processing in plastic bags at room temperature.

Nematodes were extracted from the soil and maintained in the laboratory using the wax moth Galleria mellonella Linnaeus (Lepidoptera: Pyralidae) as a susceptible host (Woodring and Kaya 1998). Last-instar G. mellonella larvae were placed in $250 \mathrm{~mL}$ plastic containers (at ten larvae each) with moistened soil from the collected samples and maintained at room temperature $\left(20 \pm 3{ }^{\circ} \mathrm{C}\right)$. The insect larvae were checked daily for two weeks to observe mortality by EPNs. The dead insects were thoroughly rinsed in distilled water and placed in a modified White trap according to the procedure described by Stock and Goodrich-Blair (2012). This technique consists of setting a moistened filter paper on a watch glass inside a Petri dish with water covering the bottom, on which paper the bodies of the insects are placed. When nematode infection has occurred, the IJs migrate from the cadaver to the water (usually at 15-20 days post-exposure). The IJs collected in this manner were subsequently stored in cell-culture flasks at $18 \pm 2{ }^{\circ} \mathrm{C}$ for eventual use in laboratory assays.

Nematode identification: Morphological and morphometric characters. The first generation of hermaphroditic females, the second of amphimictic females, males and IJs were used for morphological and morphometric studies. Adults were obtained by dissecting $G$. mellonella larvae infected by EPNs at different times $i$. e., between 3-4 (hermaphrodites), 5-7 (females and males) and 15-20 days (IJs). A total of 25 specimens from each developmental stage were considered for the determination of qualitative and quantitative data.

The nematodes thus obtained were killed in Ringer's solution at $60{ }^{\circ} \mathrm{C}$, placed in triethanolamine-formalin fixative (Kaya and Stock 1997), and solvent-dehydrated to anhydrous glycerin for mounting (Seinhorst 1959). The fixed specimens were used for drawings and measurements with the aid of a camera lucida mounted on a Zeiss microscope.

For examination by scanning electron microscopy, nematodes of different developmental stages were fixed in $3 \%$ 
(v/v) aqueous glutaraldehyde buffer $\mathrm{pH} 7.2$ for at least $48 \mathrm{~h}$ at $4-8{ }^{\circ} \mathrm{C}$. The samples were then post-fixed with $2 \%(\mathrm{w} / \mathrm{v})$ osmium-tetroxide solution for $12 \mathrm{~h}$ at $25^{\circ} \mathrm{C}$, dehydrated in a graded-ethanol series, critical-point dried with liquid $\mathrm{CO}_{2}$, mounted on specimen stubs, and coated with gold (Nguyen and Smart 1995). Observations of the ultrastructure were then made with a JEOL JSM-100 scanning electron microscope.

The following morphometric data were analyzed: L, total body length; MBW, maximum body width; ABW, analbody width; VBW, vulval-body width; EP, distance from anterior end to excretory pore; ES, distance from anterior end to base of esophagus; GuL, gubernaculum length; $\mathrm{GuW}$, gubernaculum width; NR, nerve-ring position; STL, stoma length; STW, stoma width; SpL, spicule length; SpW, spicule width; TL, tail length, TRL, testis-reflection length; D, EP/ $\mathrm{ES}$; E, EP/TL; GS, GuL/SpL; V \%, (L/length to vagina) $\mathrm{x}$ 100. In addition, for the IJs the following ratios were used: a, L/MBW; b, L/ES; c, L/TL; d, EP/ES; e, EP/TL (Table 1). The tail measurements of the IJs did not include the extra cuticle sheath (cuticle of the second stage).

Molecular-genetic analysis. To confirm the identification of the nematodes a molecular-genetic approach was performed. Thus, genomic DNAs was extracted from pools of 30 third-stage infective juveniles (IJs), by standard protocols (Sambrook et al. 1989). Briefly, specimens were first homogenized in $250 \mu \mathrm{L}$ of distilled water and then treated with $250 \mu \mathrm{L}$ of lysis solution $(10 \mathrm{mM}$ Tris $/ \mathrm{HCl}$, $\mathrm{pH} 8 ; 10 \mathrm{mM}$ EDTA, $0.25 \% \mathrm{w} / \mathrm{v}$ SDS) containing $5 \mu \mathrm{g} /$ $\mu \mathrm{L}$ proteinase $\mathrm{K}$ (Fermentas). Then, after the quality and quantity of the DNA was verified by electrophoresis and spectrophotometry (Nanodrop 1000, Thermo). The samples were used in polymerase-chain reactions (PCRs) to amplify a set of nuclear loci that contained the following sequences: the 18S-ribosomal-RNA gene (partial sequence), the internal transcribed spacers ITS 1, ITS 2, and the 5.8S and $28 \mathrm{~S}$ fragments of the ribosomal-RNA gene. Primers used [ITS-F (5'-TTGAACCGGGTAAAAGTCG-3') and ITS-R (5'-TTAGTTTCTTTTCCTCCGCT-3')] were designed by means of a previously reported protocol (Maneesakorn et al. 2011) and the thermal profile (Verity thermal cycle, Applied Biosystem) included: $94{ }^{\circ} \mathrm{C}, 2$ minutes ( 1 cycle); $92{ }^{\circ} \mathrm{C}, 15$ seconds; $55{ }^{\circ} \mathrm{C}, 15$ seconds; $72{ }^{\circ} \mathrm{C}, 1$ minute (35 cycle); $72{ }^{\circ} \mathrm{C}, 5$ minutes ( 1 cycle). The amplification products were separated by electrophoresis with molecular- weight standards used as a reference (PB-L, Argentina) and the corresponding DNAs isolated with the Zymoclean Gel DNA-recovery Kit (Zymo research) according to the manufacturer's specifications. Next, the amplicons were cloned in Escherichia coli (strain Top 10) by ligation to the pGem-T-Easy vector (Promega). After bacterial-colony selection and plasmid isolation, the inserts were identified by automated Sanger sequencing using the universal primers Sp6 and T7 (Macrogen Services).

Evaluation of the EPNs against the sap beetles: Susceptibility of $\boldsymbol{L}$. insularis stages to Heterorhabditis bacteriophora VEli. Insects were obtained from strawberry fields in La Plata $\left(34^{\circ} 56^{\prime} 35^{\prime} \mathrm{S}, 58^{\circ} 5^{\prime} 30^{\prime \prime} \mathrm{W}\right)$, Buenos Aires Province, Argentina. Adults and larvae were collected by using baited pitfall traps during the fruiting season and by examining plants and collecting ripe fruit. The pitfall traps consisted in a $0.5 \mathrm{~L}$ plastic cone, wide end up, nested inside a plastic cylinder with the latter buried to the mouth in the soil in the middle of a strawberry bed. The captured insects were later reared in the laboratory according to Blumberg et al. (1985) on the artificial diet used for Drosophila spp. (Demerec and Kaufman 1965) and maintained at $20 \pm 2{ }^{\circ} \mathrm{C}$ at a relative humidity of $70 \%$. The taxonomic identification of the sap beetles was determined by Andrew R. Cline from Plant Pest Diagnostics Branch, California Department of Food and Agriculture, Sacramento, CA, USA.

The susceptibility of each stage of $L$. insularis was tested by separately exposing larvae, pupae, and adults $(n=10)$ to the EPNs. Each stage was put in a plastic container (200 $\mathrm{ml})$ with sterile moistened clay soil $(100 \mathrm{ml})$. The larvae and adults were placed on the surface of the soil and the pupae buried at a depth of $2 \mathrm{~cm}$. To obtain parasitism over $60 \%$, a concentration of 10,000 IJs per container was used based on experiments by Glazer et al. (2007) against sap beetles. The number of individuals tested is shown in table 2. A control group with no nematodes was included in every assay. At 10 days after exposure of the sap beetles to the IJs, mortality was registered and the cadavers were placed in modified White traps to determine infectivity, emergence time and production of IJs for each stage. The number of days from the recorded mortality in the insects to the first emergence of the IJs was considered as the emergence time. The total production was determined by examination of the IJs in White traps at each interval of five days after the first

Table 1. Morphometry of the Heterorhabditis bacteriophora VEli isolate. L: total body length; MBW: maximum body width; ABW: anal-body width; VBW: vulval-body width; EP: distance from anterior end to excretory pore; ES: distance from anterior end to base of esophagus; GuL: gubernaculum length; GuW: gubernaculum width; NR: nerve-ring position; STL: stoma length; STW: stoma width; SpL: spicule length; SpW: spicule width; TL: tail length; TRL: testis-reflection length; D: EP/ES; E: EP/TL; GS: GuL/ SpL; V \%: (L/length to vagina) x 100; a: L/MBW; b: L/ES; c: L/TL; d: EP/ES; e: EP/TL. Measurements are in $\mu \mathrm{m}$ and as the mean \pm standard deviation (range).

\begin{tabular}{lcccc}
\hline \multicolumn{1}{c}{ Character } & Hermaprhroditic females & Amphimictic females & Males & Infective juveniles \\
\hline $\mathrm{L}$ & $2,835.46 \pm 482.72$ & $1,646.34 \pm 282.42$ & $822.46 \pm 83.16$ & $616.75 \pm 60.95$ \\
& $(2,160-3,840)$ & $(1,251-2,286)$ & $(711-972)$ & $(505.04-675.12)$ \\
MBW & $117.64 \pm 14.32$ & $97.08 \pm 11.89$ & $46.89 \pm 6.61$ & $25.04 \pm 1.6$ \\
& $(97.4-138.65)$ & $(78.8-113.68)$ & $(42.3-62.6)$ & $(23.2-27.84)$ \\
STL & $8.91 \pm 2.10$ & $7.76 \pm 1.36$ & $5.22 \pm 1.71$ & - \\
& $(6.25-11.6)$ & $(6.96-11.6)$ & $(2.35-4.28)$ & \\
\hline
\end{tabular}


(Continuación Tabla 1)

\begin{tabular}{|c|c|c|c|c|}
\hline Character & Hermaprhroditic females & Amphimictic females & Males & Infective juveniles \\
\hline \multirow[t]{2}{*}{ STW } & $8.16 \pm 1.34$ & $7.22 \pm 0.69$ & $4.264 \pm 1.15$ & - \\
\hline & $(5.87-9.28)$ & $(6.96-9.28)$ & $(2.35-6.9)$ & \\
\hline \multirow[t]{2}{*}{ NR } & $88.95 \pm 1.34$ & $73.69 \pm 13.56$ & $66.39 \pm 10.21$ & - \\
\hline & $(69.6-118.7)$ & $(58-104.4)$ & $(39.9-81.2)$ & \\
\hline \multirow[t]{2}{*}{ EP } & $157.65 \pm 19.89$ & $117.18 \pm 20.88$ & $110.17 \pm 22.31$ & $100.11 \pm 12.34$ \\
\hline & $(132.24-200)$ & $(83.52-173.32)$ & $(95.12-134.5)$ & $(78.8-109.04)$ \\
\hline \multirow[t]{2}{*}{ ES } & $152.58 \pm 16.41$ & $123.13 \pm 10.04$ & $116.07 \pm 12.40$ & $101.93 \pm 14.46$ \\
\hline & $(132.22-181.25)$ & $(104.4-141.52)$ & $(104.4-141.52)$ & $(74.24-113.68)$ \\
\hline \multirow[t]{2}{*}{$\mathrm{TL}$} & $47.87 \pm 9.46$ & $41.58 \pm 0.39$ & $27.95 \pm 8.47$ & $38.54 \pm 14.3$ \\
\hline & $(37.5-51.04)$ & $(20.88-53.36)$ & $(22.0-41.76)$ & $(32.16-51.4)$ \\
\hline \multirow[t]{2}{*}{ ABW } & $52.41 \pm 17.80$ & $48.36 \pm 12.30$ & $36.91 \pm 10.97$ & $18.63 \pm 3.25$ \\
\hline & $(37.12-63.45)$ & $(27.84-69.6)$ & $(27-8-44.08)$ & $(15.08-27.84)$ \\
\hline \multirow[t]{2}{*}{ V } & $42.15 \pm 12.79$ & $45.61 \pm 2.69$ & - & - \\
\hline & & $(39.2-49.68)$ & & \\
\hline \multirow[t]{2}{*}{ TRL } & - & - & $200.78 \pm 77.98$ & - \\
\hline & & & $(103.4-229.68)$ & \\
\hline \multirow[t]{2}{*}{$\mathrm{SpL}$} & - & - & $45.00 \pm 4.76$ & - \\
\hline & & & $(34.8-48.7)$ & \\
\hline \multirow[t]{2}{*}{$\mathrm{SpW}$} & - & - & $4.64 \pm 0.66$ & - \\
\hline & & & $(3.48-5.8)$ & \\
\hline \multirow[t]{2}{*}{$\mathrm{GuL}$} & - & - & $22.5 \pm 6.49$ & - \\
\hline & & & $(18.5-21.1)$ & \\
\hline \multirow[t]{2}{*}{$\mathrm{GuW}$} & - & - & $5.21 \pm 1.37$ & - \\
\hline & & & $(3.94-6.96)$ & \\
\hline \multirow[t]{2}{*}{$\mathrm{GS}(\mathrm{GuL} / \mathrm{SpL})$} & - & - & $0.53 \pm 0.13$ & - \\
\hline & & & $(0.48-0.55)$ & \\
\hline \multirow[t]{2}{*}{$\mathrm{SW}(\mathrm{SpL} / \mathrm{ABW})$} & - & - & $10.28 \pm 2.09$ & - \\
\hline & & & $(7.29-14.0)$ & \\
\hline \multirow[t]{2}{*}{$\mathrm{E}(\mathrm{EP} / \mathrm{TL})$} & - & - & $4.32 \pm 3.11$ & - \\
\hline & & & $(2.96-5.65)$ & \\
\hline \multirow[t]{2}{*}{$\mathrm{D}(\mathrm{EP} / \mathrm{ES})$} & - & - & $1.11 \pm 0.18$ & - \\
\hline & & & $(0.89-1.17)$ & \\
\hline \multirow[t]{2}{*}{$\mathrm{L} / \mathrm{TL}$} & & & $35.62 \pm 19.58$ & \\
\hline & & & $(21.36-44.18)$ & \\
\hline \multirow[t]{2}{*}{$\mathrm{L} / \mathrm{MBW}$} & - & - & $19.31 \pm 3.64$ & - \\
\hline & & & $(13.5-22.97)$ & \\
\hline \multirow[t]{2}{*}{$\mathrm{MBW} / \mathrm{TL}$} & - & - & $1.57 \pm 1.09$ & - \\
\hline & & & $(1.1-2.7)$ & \\
\hline \multirow[t]{2}{*}{ Ratio a (L/MBW) } & - & - & - & $23.76 \pm 3.03$ \\
\hline & & & & $(22.2-26.2)$ \\
\hline \multirow[t]{2}{*}{ Ratio b (L/ES) } & - & - & - & $6.19 \pm 1.2$ \\
\hline & & & & $(5.3-8.8)$ \\
\hline \multirow[t]{2}{*}{ Ratio c (L/TL) } & - & - & - & $9.87 \pm 3.63$ \\
\hline & & & & $(6.2-14.4)$ \\
\hline Ratio d (EP/ES) & - & - & - & $0.99 \pm 0.14$ \\
\hline & & & & $(0.62-1.07)$ \\
\hline Ratio e (EP/TL) & - & - & - & $1.54 \pm 0.39$ \\
\hline & & & & $(1.9-2.1)$ \\
\hline
\end{tabular}


appearance of the nematodes, until no further emergence was recorded. The total number was determined by the method of dilution: One $\mathrm{ml}$ of the initial suspension of IJs was diluted with $5 \mathrm{ml}$ of distilled water, the suspension agitated vigorously, and 5 aliquots $(1 \mathrm{ml})$ counted (Stock and Goodrich-Blair 2012).

The subsequent serial infectivity of IJs emerged from infected $L$. insularis was also evaluated. Tests were performed in 10-cm Petri dishes with ten G. mellonella larvae as a sensitive host and 1,000 IJs. Mortality was determined every $24 \mathrm{~h}$ and the dead insects placed in White traps to corroborate the emergence of nematodes from infected individuals. Six replicas were performed.

All assays were realized at $20^{\circ} \mathrm{C}$ and at a relative humidity of $70 \%$.

Lethal-concentration determination $\left(\mathbf{L C}_{50}\right.$ and $\left.\mathbf{L C}_{90}\right)$. The concentration needed for the EPNs to kill $50 \%$ and $90 \%$ of the L. insularis larvae $\left(\mathrm{LC}_{50}\right.$ and $\left.\mathrm{LC}_{90}\right)$ were determined. Larvae were added to plastic 200 -ml containers $(n=10)$ with autoclaved clay soil $(100 \mathrm{ml})$ obtained from horticultural gardens along with concentrations of $0 ; 1,000 ; 5,000$ and 10,000 IJs per container. Only larvae of $L$. insularis were considered for tests, for being the main target to control this pest with EPNs due to its high susceptibility and behavior in the field, falling to the ground and bury themselves to pupate. The number of individuals tested is shown in table 3. The mortality was assessed 10 days post-exposure and the cadavers were placed in modified White traps to determine emergence of IJs. Total production of IJs and the time of emergence at each concentration were measured as was described previously for bioassays of susceptibility.

Parasitism by EPNs on adults of $L$. insularis in containers with strawberries as attractant food. To determine whether strawberries applied to the containers as food attractants of adults increase the susceptibility to EPNs, six containers with 10 adults each one were provided with a ripe strawberry and another six were left with no food (total adults: 120). A concentration of 10,000 JIs per container was used. Strawberries were obtained from plants grown in the greenhouse of the CEPAVE institute (Sweet Ann strain). They presented a size between 3 and $4 \mathrm{~cm}$ long and $75 \%$ of the red fruit, value considered by the maturity index established by SENASA (National Agri-Food Quality and Health Service of Argentina) for mature fruits. A control group $(n=10)$ without nematodes was included in each assay. Mortality was registered at 10 days after exposure of the sap beetles, and the cadavers placed in modified White traps to determine IJ emergence and thus corroborate infectivity by the EPNs.
Data analyses. For the determination of the lethal concentrations $\left(\mathrm{LC}_{50}\right.$ and $\left.\mathrm{LC}_{90}\right)$, a probit model that relates $\log 10$ (concentration) to the probit was used with the Ecotoxicology library (V 1.0.1), implemented in R, and the Probit EPA function that simulates the EPA's proven EERD (Ecological Exposure Research Division).

The infectivity of $H$. bacteriophora by concentration and stage were analyzed by binomial test of proportions. A global type I error of 0.05 was adjusted to 0.0169 by the experimentwise error rate, due to the three pairs of comparisons (3) to be tested (Lyman Ott and Longnecker 2010). To compare the production, the data were normalized by applying natural logarithm showing to be homoscedastic (Levene test with $p$-value $=0.7748$ ) and then an analysis of variance (ANOVA) was used. A Kruskall - Wallis comparison was considered to detect differences between the medians of the emergency times, and assays of food attractants. Differences in median emergency between concentrations were detected by the Mann - Whitney - Wilcoxon test (Hollander et al. 2014).

\section{Results}

Identification of nematodes. The analyses of morphology and molecular genetics carried out enabled us to determine an isolate of $H$. bacteriophora. The strain was designated as VEli according to the sampling site of origin (i.e. Villa Elisa) being the first documentation of an EPN for that locale and the second for the Buenos Aires province.

The morphology proved to be similar to that described for other H. bacteriophora populations. The adults (in general) are with the head from truncate to slightly rounded; six different lips surround the mouth opening, each one bearing an inner labial papilla. At the base of each sub-dorsal and sublateral lip are two additional papillae representing an outer labial papilla and a cephalic papilla (Fig. 1D). The base of each lateral lip contains an elliptical amphidial opening and an outer labial papilla, while the stoma is mostly collapsed (Figs. 1C-D).

The females are variable in size, with an amphidelphic reproductive system that is reflexed past the vulval opening. The dioecious females are with a nonfunctional vulva for oviposition and a pointed tail (Figs. 2A-B). The hermaphroditic female is thin and elongated with a truncated anterior end, an open vulva functional for oviposition, and the anal region slightly protruding (Figs. 2C-D).

The males have a single reflexed testis, spicules paired and separate, the peloderan bursa supported by nine pairs of papillae: a small anterior pair, two pairs adjacent to the spicules, and six pairs distal to the anal opening. The latter six are in two sets of three (Figs. 1A-B).

Table 2. Mortality and infectivity of larvae, pupae, and adults of Lobiopa insularis exposed to a concentration of 10,000 infective juveniles per container of the entomopathogenic nematode Heterorhabditis bacteriophora Strain VEli.

\begin{tabular}{lcccccc}
\hline Stage & N evaluated & N killed & N infected & $\begin{array}{c}\text { Production of } \\
\text { IJs/individual }\end{array}$ & $\begin{array}{c}\text { Infectivity } \\
\text { (\%) }\end{array}$ & $\begin{array}{c}\text { Emergence } \\
\text { time (days) }\end{array}$ \\
\hline Larvae & 240 & 185 & 185 & $840-7,600$ & $77.10 \pm 16.70$ & $11-22$ \\
Pupae & 270 & 173 & 173 & $1,200-5,000$ & $64.10 \pm 25.41$ & $20-30$ \\
Adults & 180 & 3 & 3 & $1,360-4,400$ & $1.7 \pm 4.1$ & $21-25$ \\
\hline
\end{tabular}


Table 3. Mortality, infectivity, production, and emergence time in larvae of Lobiopa insularis exposed to different concentrations of the entomopathogenic nematode Heterorhabditis bacteriophora VEli.

\begin{tabular}{ccccccc}
\hline $\begin{array}{c}\text { Concentration } \\
\text { (IJs/ container) }\end{array}$ & N evaluated & N killed & N infected & $\begin{array}{c}\text { Production of } \\
\text { IJs/larva }\end{array}$ & $\begin{array}{c}\text { Infectivity } \\
(\%)\end{array}$ & $\begin{array}{c}\text { Emergence } \\
\text { time (days) }\end{array}$ \\
\hline 1,000 & 40 & 10 & 10 & $1,090-9,247$ & $25.00 \pm 12.91$ & $7-14$ \\
5,000 & 30 & 17 & 17 & $891-7,190$ & $56.67 \pm 11.55$ & $7-9$ \\
10,000 & 240 & 185 & 185 & $840-7,600$ & $77.10 \pm 16.70$ & $11-22$ \\
\hline
\end{tabular}

The IJs have a head bearing a dorsal tooth (Fig. 2F); a cuticle with two double lateral lines; the body, with a tessellate pattern (Fig. 2F), covered by the enclosing secondstage cuticle; and the tail pointed (Fig. 2E).

Table 1 lists the morphologic measurements. Fertilized females were not considered for morphometric features due to the intra-uterine birth causing maternal death (endotokia matricida) a phenomenon common in rhabditid nematodes and typical for entomopathogenic nematodes of the Heterorhabditis genus (Figs. 2A, C).

The sequences of genomic-DNA fragments determined in the VEli strain -consisting of part of the 18S, ITS1, 5.8S, and ITS2 loci plus a portion of the $28 \mathrm{~S}$ locus (901 bp including the PCR primers)- were registered in the Genbank public database (accession number: KJ575524). The subsequent bioinformatic analyses that we carried out enabled us to conclude that this nematode was an authentic isolate of Heterorhabditis bacteriophora.

Examined material: Heterorhabditis bacteriophora strain VELi. Hermaphrodites, females, males and IJs (=25). ARGENTINA. Buenos Aires province. Municipality of La Plata. Villa Elisa $34^{\circ} 51^{\prime} 12^{\prime \prime}$ S 58 $04^{\prime} 45^{\prime \prime} \mathrm{W} 9.87$ masl 27May-2014. Collected by Daiana Eliceche, and registered in the Museum of La Plata under the sample designation [MLPHe 6725].

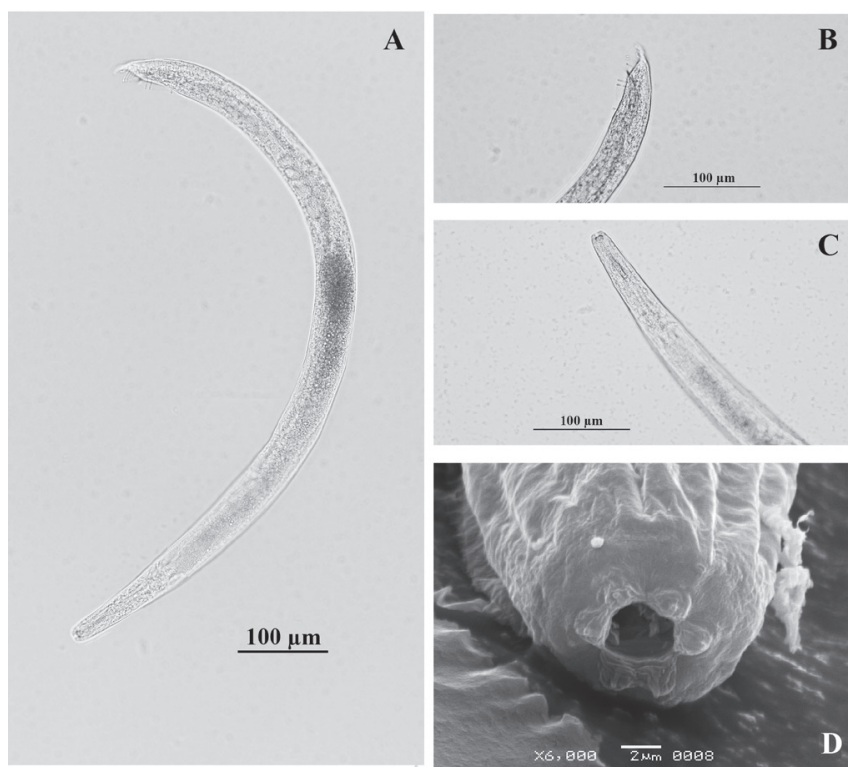

Figure 1. Light and scanning-electron-microscopy photographs of Heterorhabditis bacteriophora Strain VEli male. A. Entire worm. B. Posterior end, with bursal papillae, lateral view, spicule and gubernaculum. C. Anterior end. D. Frontal view showing amphidial aperture.
Evaluation of the EPNs against the sap beetles: Susceptibility of $L$. insularis stages to Heterorhabditis bacteriophora VEli. The degree of infectivity in the three stages was significantly different $(\mathrm{P}<0.0013)$. Infectivity was higher in larvae and pupae $(77 \pm 17 \%$ and $64 \pm 25 \%$, respectively) than in the adults $(2.2 \pm 1.1 \%$; Table 2$)$. The cadavers presented purple color (Figs. 3A-F).

Lethal-concentration determination $\left(\mathrm{LC}_{50}\right.$ and $\left.\mathbf{L C}_{90}\right)$. A mortality of $25-77 \%$ was caused by $H$. bacteriophora VEli in L. insularis larvae at the three concentrations tested. The highest mortality was obtained at a concentration of 10,000 IJs per container (Table 3). The three comparisons showed a lower significance level than the one proposed by experimentwise (0.0169), therefore the infectivity was different in each concentration. The lethal concentration required to kill 50 and $90 \%$ of the larvae $\left(\mathrm{LC}_{50}\right.$ and $\left.\mathrm{LC}_{90}\right)$ over 10 days was 2,840 IJs/container (lower fiducial limit $=268$; upper fiducial limit $=5,130$ ) and $23,743 \mathrm{IJs} /$ container (lower fiducial limit $=11,952$; upper limit $=597,190$ ) respectively (Fig. 4; Table 4). The cadavers were always observed purple color.

Parasitism by EPNs on adults of $L$. insularis in containers with strawberries as attractant food. Low

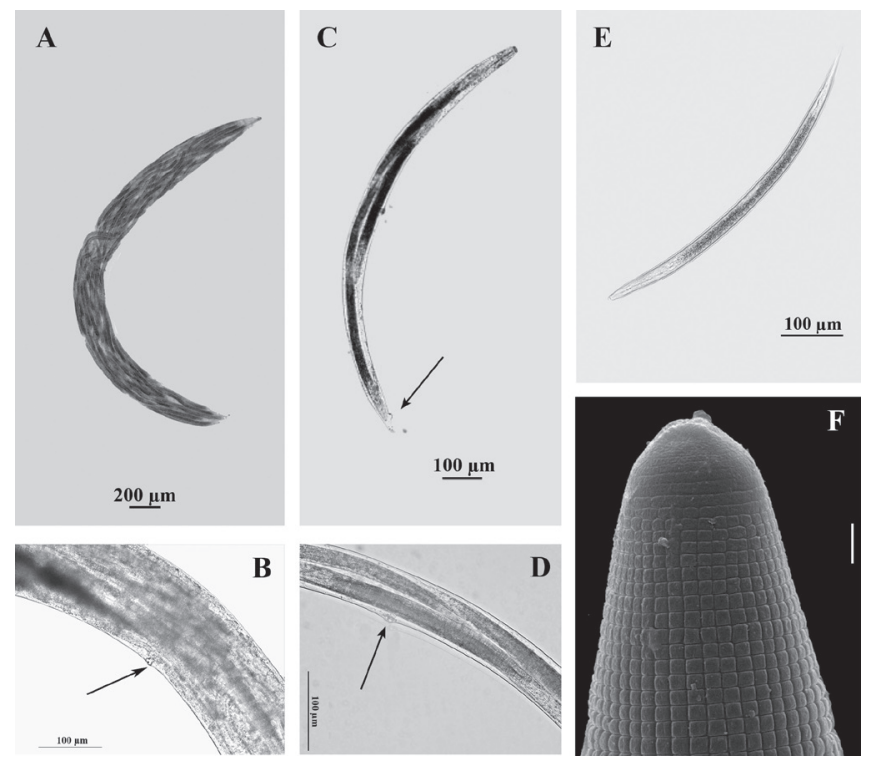

Figure 2. Light and scanning-electron-microscopy photographs of Heterorhabditis bacteriophora Strain VEli. Amphimictic female (AB). A. Endotokia matricida. B. Vulva región. Hermaphroditic female (C-D). C. Endotokia matricida showing vulva and anal region slightly protruding. D. vulva region. E. Entire infective juvenile. F. Tooth and tessellate pattern of the infective juvenile: scale bar: $2 \mu \mathrm{m}$. 

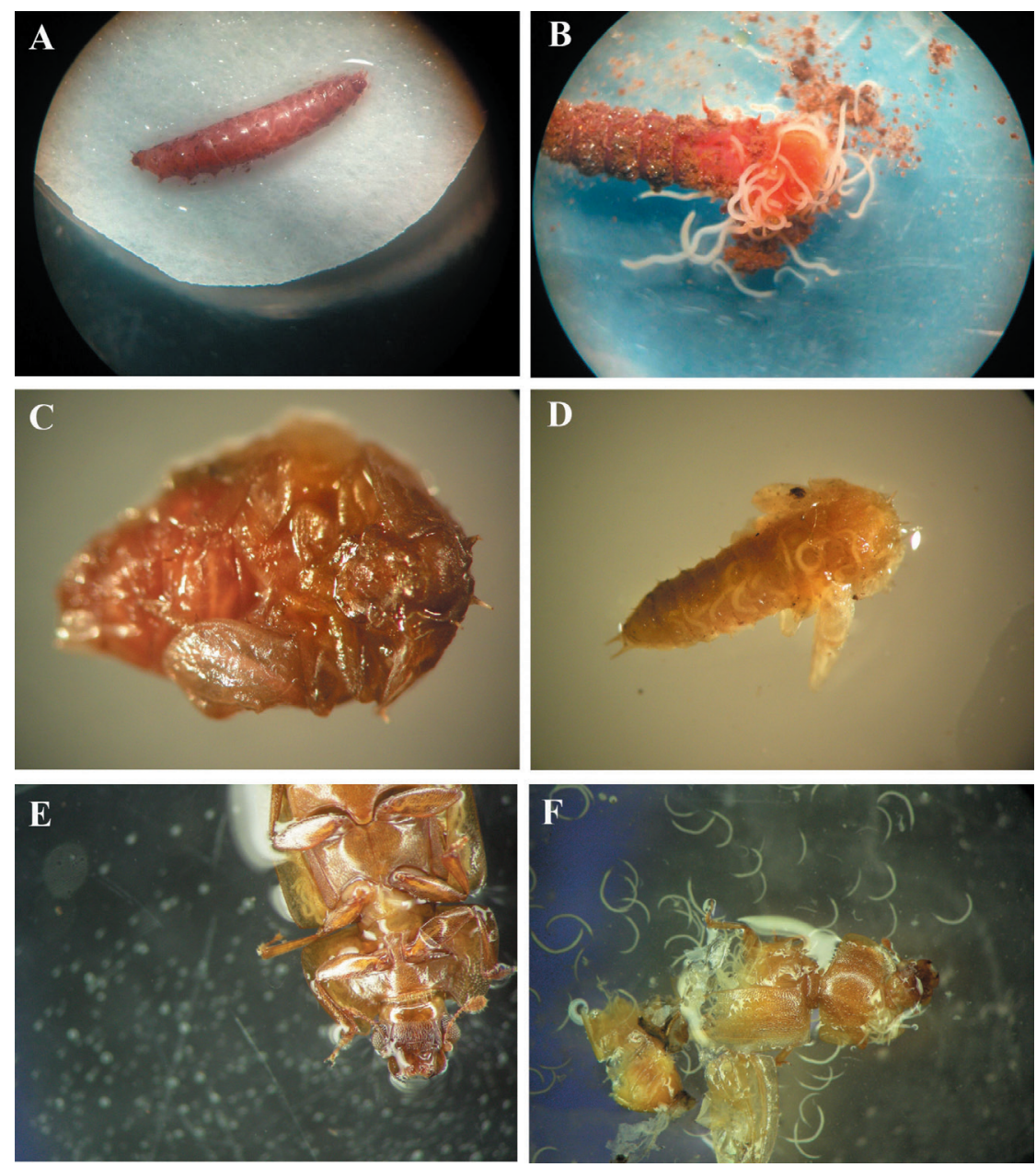

Figure 3. Lobiopa insularis infected by Heterorhabditis bacteriophora VEli according to stage. A-B. Larvae. C-D. Pupae. E-F. Adults.

parasitism by EPNs was determined in containers with and without a supply of strawberries $(10.00 \pm 0.00 \%$ and $2.2 \pm$ $1.1 \%$, respectively). However, significant differences were observed $(\mathrm{P}=0.019)$.

IJ-production capacity and EPN-emergence time. The total IJ production obtained from cadavers from different

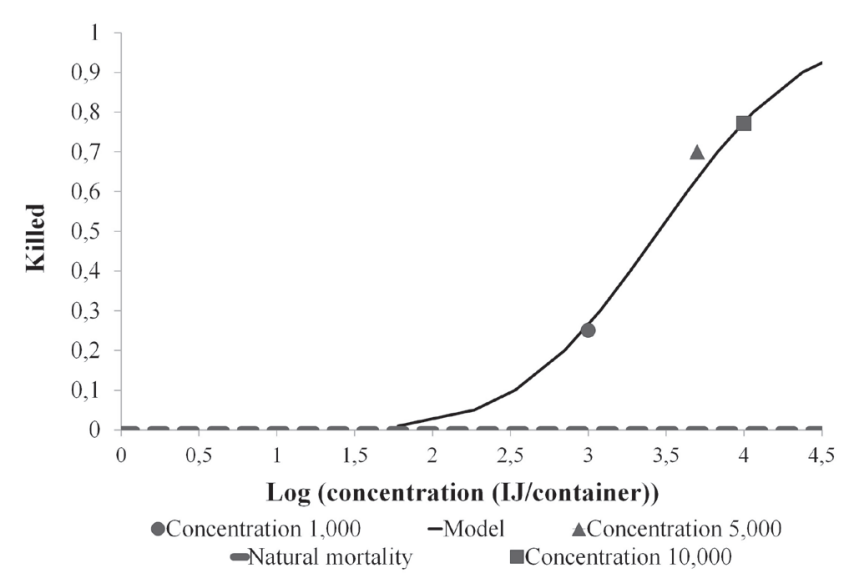

Figure 4. Lobiopa insularis larval mortality (\%) and lethal concentrations $\left(\mathrm{LC}_{50}\right.$ and $\mathrm{LC}_{90}$ ) after 10 days exposition to $H$. bacteriophora $\mathrm{VELi}$ (IJs).
L. insularis stages and concentrations, ranged between 840 and 9,247 individuals, reaching maximum values in larvae at a concentration of 1,000 JIs per container (Tables 2, 3). However, analysis of variance did not indicate differences due to concentration $(\mathrm{F}=0.4381, \mathrm{df}=(2,12), \mathrm{P}=0.6552)$ or stage $(\mathrm{F}=0.1559, \mathrm{df}=(2,10), \mathrm{P}=0.8577)$.

The initiation of IJ emergence from the dead insects occurred between 11 and 22 days post-exposure for larvae, 20 and 30 days for pupae, and 21 and 25 days for adults (Table 2). In the larvae, emergence of IJs occurred during a less extended period of time than for the pupae or adults (Table 2).

A longer time interval was observed at a concentration of 10,000 JIs per container relative to the corresponding intervals for the lower concentrations (11-22 days, Table 3). The Kruskal - Wallis test, determined significant differences among the medians of the emergence times $\left(\chi^{2}=6.33\right.$; $\mathrm{df}=$ 2; $\mathrm{P}=0.04)$. Comparing scores of two with Mann - Whitney - Wilcoxon test adjusted significance of 0.0169 , the only significant difference was between concentration of 5,000 and $10,000(\mathrm{P}=0.01322)$ and between larvae and pupae $(\mathrm{P}=$ 0.429 ).

The JIs emerged from $L$. insularis were pathogenic in reinfections with a mean value of $70 \pm 16 \%$, and produced new generations of IJs. 
Table 4. Lethal Concentration values and confidence limits in $\mathrm{R}$ (Version $1.0 .143^{\circ} 2009-2016$ RStudio, Inc.).

\begin{tabular}{cccc}
\hline \multirow{2}{*}{ Probability } & \multirow{2}{*}{$\begin{array}{c}\text { Lethal } \\
\text { Concentration }\end{array}$} & \multicolumn{2}{c}{$\mathbf{9 5 \% \text { Confidence Limits }}$} \\
\cline { 3 - 4 } & 60.11 & Lower & Upper \\
\hline 0.01 & 185.95 & 0.00 & 447.79 \\
0.05 & 339.52 & 0.03 & 879.43 \\
0.10 & 509.66 & 0.21 & $1,265.73$ \\
0.15 & $2,839.28$ & 0.84 & $1,623.16$ \\
0.50 & $15,817.54$ & 267.97 & $5,130.39$ \\
0.85 & $23,743.94$ & $11,951.57$ & $157,962.91$ \\
0.90 & & & $597,190.33$ \\
\hline
\end{tabular}

\section{Discussion}

Heterorhabditis bacteriophora populations have been recorded in a range of different habitats from Argentina (Stock 1995; Doucet and Bertollotti 1996; Doucet et al. 2001; Giayetto and Cichón 2006; Del Valle et al. 2013). In the Buenos Aires province, only a single record had been reported by Stock (1995) for the town of City Bell, but without records of molecular and morphometric data.

Geographical origin and habitat can influence nematode morphology. Studies on the morphometric variability can be useful in providing valuable information about the geographical and ecologic requirements for EPNs (Stock et al. 2000; 382 Lacey and Georgis 2012). Accordingly, morphological and morphometric features of the population of $H$. bacteriophora reported here are first for Buenos Aires province.

Because $H$. bacteriophora VEli killed L. insularis in all developmental stages, we consider this new isolate to be a potential biological control agent. EPNs were able to complete their life cycle in larvae, pupae, or adults, a capability that would improve the establishment and spread of the strain in its natural habitat. In all experiments, a change in the host body color (dark red to purple) caused by symbiotic bacteria was observed, thus confirming infection. Likewise, previous studies have demonstrated Heterorhabditis spp. to have high potential for use as a control agent for sap beetles (Carpophilus sp.) in a date-palm orchard and recorded a substantial reduction (50-70\%) in insect emergence in the field (Glazer et al. 2007).

A higher level of infectivity and longer period of emergence time was obtained in L. insularis larvae for the highest concentration (10,000 IJs per container), but a lower production of IJs was registered. The reason of the differences could be related to the level of infectivity obtained. A higher percentage of parasitism indicates that more nematodes have penetrated the host and are residing inside having to share the same resources. The more limited availability of nutrients per nematode likely interferes in its development thus resulting in a lower number of generations for the subsequent production of IJs. A limit in the supply of nutrients available to the nematode because of an interaction with the host immune system, and/or a reduced reproduction of symbiotic bacteria can result in a lower total generation of IJs inside a particular host (Forst and Clarke 2002).

The variation in the infectivity, time to first emergence, and total number of IJs between stages of L. insularis may also have resulted from differences in development time of the EPNs and differential susceptibility among the stages, as was observed for other insects (Koppenhofer and Fuzy 2004). A variety of reasons have been given to explain such observed differences, including the size, immune response, behavior, and nutritional condition of the host, such as the type of nutrients produced by the symbiotic bacteria (Shapiro et al. 1999).

Strategies for controlling sap beetles are farming practices and insecticide applications. A challenge in the production of strawberries is to obtain fruit with acceptable pesticide residue levels without compromising fruit quality or environmental sustainability.

EPNs have been used with varying degrees of success against pest insects that exit fruit and pupate in the soil. They are an environmentally safe means of pest management and may be an alternative to chemical insecticides (Lacey and Georgis 2012). However, EPNs are produced and marketed by only a few companies with mainly nonnative strains being used for applications. Strains adapted to local environmental and climatic conditions would offer distinct advantages for the management of local pests from the standpoint of adaptability and ecological compatibility (Lewis et al. 2006). The results of our study indicate that EPNs effectively kill all L. insularis stages and complete their development in a time similar to that of other EPNs in other hosts. In addition, IJs emerging from $L$. insularis are infective, thus insuring the nematode's maintenance in the field through subsequent reinfections.

\section{Acknowledgements}

This study was partially supported by Consejo Nacional de Investigaciones Científicas y Técnicas (CONICET), Universidad Nacional de La Plata, (UNLP), and Agencia Nacional de Promoción Científica y Tecnológica, Argentina, PICT 2011/1439. We thank to Dr. Graciela Minardi, (CEPAVE), for statistical assistance and Dr. Donald F. Haggerty, a retired academic career investigator and native English speaker, for editing of the final version of the manuscript.

\section{Literature cited}

BLUMBERG, D.; DORON, S.; BITTON, S. 1985. Effect of triflumuron on two species of nitidulid beetles, Carpophilus hemipterus and Urophoru shumeralis. Phytoparasitica 13: 9-19.

BORTOLI, L. C.; MACHOTA JUNIOR, R.; BOTTON, M. 2014. Biologia e tabela de vida de fertilidade da brocado-morangueiro criada em dieta artificial. Pesquisa Agropecuária Brasileira, Brasília 49 (2): 144-147.

BOTTON, M.; BERNARDI, D.; FORNARI, R.; MACHOTA JUNIOR, R.; BORTOLI, L. 2014. Biologia, monitoramento e controle de Lobiopa insularis (Castelnau, 1840) (Coleoptera: Nitidulidae) na cultura do morangueiro no Rio Grande do Sul. Circular técnica 113. Bento Gonçalves, RS. 8 p.

BOWEN, D.; ROCHELEAU, T.; BLACKBURN, M.; ANDREEV, O.; GOLUBEVA, E.; BHARTIA, R.; FFRENCH-CONSTANT, R.; 1998. Insecticidal toxins from the bacterium Photorhabdus luminescens. Science 280 (5372): 2129-2132.

CAMPOS-HERRERA, R.; GOMEZ-ROS, M.; ESCUER, M.; LUIS CUADRA, M.; BARRIOS, L.; GUTIERREZ, C. 2008. Diversity, occurrence, and life characteristics of natural entomopathogenic nematode populations from La Rioja (Northern Spain) under different agricultural management and their relationships with soil factors. Soil Biology and Biochemistry 40: 1474-1484. 
CLUIGT, N.; GRECO, N.; LILJESTRÖM, G. 2007. Características de la historia de vida de Lobiopa insularis (Coleoptera: Nitidulidae) en frutilla. En resumen de $30^{\circ}$ Congreso Argentino de Horticultura. Asociación Argentina de Horticultura (ASAHO). La Plata 2007.

DEMEREC, M.; KAUFMAN, B. 1965. Drosophila guide, introduction to the genetics and cytology of Drosophila melanogaster. Carnegie Institution of Washington. Washington D.C. 45 p.

DEL VALLE, E.; LAX, P.; RONDÁN DUEÑAS, J.; DOUCET, M. 2013. Effects of insect cadavers infected by Heterorhabditis bacteriophora and Steinernema diaprepesi on Meloidogyne incognita parasitism in pepper and summer squash plants. Ciencia e Investigación Agraria 40 (1): 109-118.

DOUCET, M. DE.; BERTOLOTTI, M. 1996. Una nueva población de Heterorhabditis bacteriophora Poinar, 1975 para Argentina. Caracterización y acción sobre el huésped. Nematologica Mediterranea 24: 169-174.

DOUCET, M. DE.; BERTOLOTTI, M.; CAGNOLO, S.; DOUCET, M.; GIAYETTO, A. 2001. Consideraciones acerca de nematodos entomófagos (Mermithidae, Heterorhabditidae, Steinernematidae) de la Provincia de Córdoba. Boletín de la Academia Nacional de Ciencias 66: 75-85.

DOWD, P.; MOORE, D.; VEGA, F.; MCGUIRE, M.; BARLET, R.; NELSON, T.; MILLER, D. 1995. Occurrence of a mermithid nematode parasite of Carpophilus lugubris (Coleoptera: Nitidulidae) in Central Illinois. Journal of Environmental Entomology 24: 1245-1251.

FERRATTO, J.; MONDINO, M.; GRASSO, R.; ORTIZ MACKINSON, M.; LONGO, A.; CARRANCIO, L.; FIRPO, I.; ROTONDO, R.; ZEMBO, J.; CASTRO, G.; GARCÍA, M.; RODRIGUEZ FAZZONE, M.; IRRIBARREN, M. 2010. Buenas prácticas agrícolas para la agricultura familiar. Cadena de las principales hortalizas de hojas en Argentina. Editorial FAO, INTA, y Facultad de Ciencias Agrarias, UNR, Rosario. Argentina. $535 \mathrm{p}$.

FORNARI, R.; MACHOTA, R.; BERNARDI, D.; BOTTON, M.; LUIZ PASTORI, P. 2013. Evaluation of damage, food attractants and population dynamics of strawberry sap beetle. Horticultura Brasileira 31: 380-385.

FORST, S.; CLARKE, D. 2002. Bacteria-Nematode symbiosis. pp. 57-77. In: Gaugler, R. (Ed.). Entomopathogenic nematology. CABI Publishing. Guilford. UK. 388 p.

GIAYETTO, A.; CICHÓN, L. 2006. Distribución, gama de huéspedes y especificidad de cinco poblaciones de Heterorhabditis bacteriophora (Nematoda: Heterorhabditidae) del Alto Valle de Río Negro y Neuquén, Argentina. RIA 35 (2): 163-183.

GLAZER, I.; ELIYAU, M.; SALAME, L.; NAKASH, Y.; BLUMBERG, D. 2007. Evaluation of the efficacy of the entomopathogenic nematodes Heterorhabditis sp. against sap beetles (Coleoptera: Nitidulidae). Biocontrol 52: 259. 270.

GUIMARÃES, J.; MICHEREFF FILHO, M.; RIBEIRO, M.; LIZ R.; GUEDES, I. 2009. Ocorrência e manejo da broca do morangueiro no Distrito Federal. Comunicado Técnico. Embrapa, Brasilia, 5 p.

GRECO, N.; CLUIGT, N.; CLINE, A.; LILJESTHRÖM, G. 2017. Life history traits and life table analysis of Lobiopa insularis (Coleoptera: Nitidulidae) fed on strawberry. PLoS ONE 12 (7): e0180093. https:// doi.org/10.1371/journal.pone.0180093.

GREWAL, P.; PETERS, A. 2005. Formulation and quality control of entomopathogenic nematodes. pp. 79-90. In: Grewal, P; Ehlers, R.; Shapiro-Ilan, D. (Eds.). Nematodes as biocontrol agents. CABI Publishing, Wallingford, UK. 528 p.

HOLLANDER, M.; WOLFE, D.; CHICKEN, E. 2014. Nonparametric statistical methods. John Wiley and Sons, New Jersey. 809 p.
IMBELlONE, P.; GIMÉNEZ, J.; PANIGATTI, J. 2010. Suelos de la Región Pampeana: Procesos de formación. INTA, Buenos Aires. 320 p.

KAYA, H.; STOCK, P. 1997. Techniques in insect nematology. pp. 281-324. In: Lacey, L. (Ed.). Biological techniques "Manual of techniques in insect pathology". Academic Press, London. $409 \mathrm{p}$.

KOPPENHOFER, A.; FUZY, E. 2004. Effect of white grub developmental stage on susceptibility to entomopathogenic nematodes. Journal of Economic Entomology 97 (6): 18421849.

LACEY, L.; GEORGIS, R. 2012. Entomopathogenic nematodes for control of insect pests above and below ground with comments on commercial production. Journal of Nematology 44 (2): 218225.

LACEY, L.; GRZYWACZ, D.; SHAPIRO-ILAN, D.; FRUTOS, R.; BROWNBRIDGE, M.; GOETTEL, M. 2015. Insect pathogens as biological control agents: back to the future. Journal of invertebrate Pathology 132: 1-41.

LASOŃ, A.; PRZEWOZNY, M. 2009. Lobiopa insularis (Castelnau, 1840) (Coleoptera: Nitidulidae: Nitidulinae) an introduced beetle species new for the Palaearctic fauna. Polish Journal of Entomology 78: 347-350.

LEWIS, E.; CAMPBELL, J.; GRIFFIN, C.; KAYA, H.; PETERS, A. 2006. Behavioral ecology of entomopathogenic nematodes. Biological Control 38: 66-79.

LIN, H.; PHELAN, P. 1991. Identification of food volatiles attractive to Glischrochilus quadrisignatus and Glischrochilus fasciatus (Coleoptera: Nitidulidae). Journal of Chemical Ecology 17 (12): 2469-2480.

LYMAN OTT, R., LONGNECKER, M. 2010. An introduction to statistical methods and data analysis. Sixth edition. Brooks/Cole CENAGE Learning, Belmont, USA. $571 \mathrm{p}$.

MANEESAKORN, P.; DANESHVAR, H.; TAYLOR, K.; BAI, X.; ADAMS, B.; GREWAL, P.; CHANDRAPATYA, A. 2011. Phylogenetic and co-phylogenetic relationships of entomopathogenic nematodes (Heterorhabditis: Rhabditida) and their symbiotic bacteria (Photorhabdus: Enterobacteriaceae). Molecular Phylogenetics and Evolution 59 (2): 271-280.

MYERS, L. 2014. Sap beetles (of Florida), Nitidulidae (Insecta: Coleoptera: Nitidulidae). Featured creatures series, Entomology and Nematology Department, University of Florida. Available: http://edis.ifas.ufl.edu/IN525 [Review date: 26 July 2014].

NICHOLS ESTRADA, C. 2008. Control biológico de insectos. Un enfoque agroecológico. Editorial Universidad de Antioquia, Medellín. 278 p.

NGUYEN, K.; SMART, G. JR. 1995. Scanning electron microscope studies of Steinernema glaseri (Nematoda: Steinernematidae). Nematologica 41: 183-190.

POTTER, M.; PRICE, J.; HABECK, D.; SCHUSTER, D.; MCCORD, E. Jr. 2013. A survey of sap beetles (Coleoptera: Nitidulidae) in strawberry fields in West Central Florida. Florida Entomologist 96 (3): 1188-1189.

SAMBROOK, J.; FRITSCH, E.; MANIATIS, T. 1989. Molecular cloning. A laboratory manual. Second edition. Cold Spring Harbor Laboratory Press, New York. 1626 p.

SEINHORST, J. 1959. A rapid method for the transfer of nematodes from fixative to anhydrous glycerin. Nematologica 4: 117-128.

SHAPIRO, D.; CATE, J.; J. PENA, J.; HUNSBERGER, A.; MCCOY, C.1999. Effects of temperature and host age on suppression of Diaprepes abbreviatus (Coleoptera: Curculionidae) by entomopathogenic nematodes. Journal of Economic Entomology 92: 1086-1092.

SHAPIRO-ILÁN, D.; DOLINSKI, C. 2012. Entomopathogenic nematode production and application technology. Journal of Nematology 44 (2): 206-217. 
STOCK, P. 1995. Natural populations of entomopathogenic nematodes in the Pampean Region of Argentina. Nematropica 25: $143-148$.

STOCK, P.; GOODRICH-BLAIR, H.2012. Techniques in insect nematology. pp. 281-324. In: Lacey, L. (Ed.). Biological techniques "Manual of techniques in insect pathology". Academic Press of Elsevier, San Diego. 50 p.

STOCK, P.; MRACEK, Z.; WEBSTER, J. 2000. Morphological variation among selected allopatric populations of Steinernema kraussei (Steiner, 1923) (Rhabditida, Steinernematidae). Nematology 2: 143-152.

VEGA, F.; KAYA, H. 2012.Insect pathology, second edition. Academic Press, San Diego. 508 p.

WOODRING, J.; KAYA, H. 1998. Steinernematid and heterorhabditid nematodes: a handbook of techniques. South Co-operative Service Bulletin 331: 1-30.
Received: 11-Jun-2015 • Accepted: 22-Sep-2017

Suggested citation:

ELICECHE, D. P.; BELAICH, M. N.; GHIRINGHELLI, P. D.; ACHINELLY, M. F. 2017. Heterorhabditis bacteriophora pampean-strain VEli (Nematoda): identification and pathogenicity against the strawberry pest Lobiopa insularis (Coleoptera: Nitidulidae). Revista Colombiana de Entomología 43 (2): 223232. Julio - Diciembre 2017. ISSN: 0120-0488. 